\title{
Dynamics of Isomerization of Hop Alpha-Acids and Transition of Hop Essential Oil Components in Beer
}

\author{
Miha Ocvirk ${ }^{1}$ and Iztok J. Košir ${ }^{1, *}$ \\ ${ }^{1}$ Institute of Hop Research and Brewing, Cesta Žalskega Tabora 2, SI-3310 Žalec, Slovenia \\ *Corresponding author: E-mail: iztok.kosir@ihps.si \\ Tel: 0038637121608
}

Received: 01-13-2020

\begin{abstract}
Hops' unique composition of essential oil components and bitter resins are crucial for beer aroma, which is important to consumers' acceptance of beer. In this experiment the same wort was divided into four portions and each was hopped differently. To determine the dynamics of isomerization rates the concentrations of alpha- and iso-alpha-acids were continuously measured. Measurements of hop essential oil components were performed during each process to understand the dynamics of the transition into beer. The maximum isomerization yield of alpha-acids (18.1\%) was achieved after $100 \mathrm{~min}$. Longer boiling increased the reduction of iso-alpha-acids, as well as essential oil components. Dry hopping also affected not only on beer aroma but also on beer bitterness.
\end{abstract}

Keywords: Beer; hop; aroma; isomerization; hop essential oil

\section{Introduction}

In the brewing process hop is a quantitatively minor ingredient, but of paramount importance to the brewing industry. With their complex chemistry, hops have been the subject of investigation for decades. ${ }^{1}$ During the brewing process hops are added into the boiling wort to provide a bitter taste and aroma to the final product. ${ }^{2}$ One of the main reasons for boiling the wort is the isomerization reaction of the hop alpha-acids into their isomerized forms. The duration of kettle hopping depends on the time required for the isomerization to take place. ${ }^{3}$ Adding hops into the boiling wort is desired with intent to achieve the desired bitterness, however it causes a reduction in the yield of essential oils in the beer due to evaporation. Consequently, these components are not present in beer in the same ratios as they are in hops. Some components are very volatile and some have low solubility in water. ${ }^{4}$

During other stages of the brewing process, essential oil components decrease because of adsorption of yeast cells on the trub in addition to evaporation. The $\mathrm{CO}_{2}$ produced during alcoholic fermentation also affects the decrease of aroma compound yields in beer. ${ }^{5-8}$ To avoid the loss of aroma constituents and to achieve better yields dry hopping technique is in use, where hops are added at a later stages of brewing process, during fermentation or maturation.
The volatile aroma compounds of the hops are crucial for brewers, since they give beer its unique aroma. The identification of hop essential oil composition lasts for decades and the study of Roberts et.al concluded on the presence of over 1000 compounds in an oil fraction. ${ }^{9}$ Dried hops contain approximately $0.5-4.0 \%$ of essential oils. According to the chemical composition, compounds can be divided into three groups depending on their chemical structure: the hydrocarbon fraction which form approximately $75 \%$ of the total oil, the oxygen containing compounds forming approximately $25 \%$ of the total oil and the sulphur-containing compounds present in much lower quantities. ${ }^{2,10}$ Hydrocarbon fraction, consists of monoterpenes, sesquiterpenes and aliphatic hydrocarbons. Due to evaporation and low solubility in water, concentrations of these group of aroma compounds are very low in finished beer. Presence of alcohol in beer can increase solubility of monoterpenes. Oxygen containing compounds consist mostly of monoterpenic, sesquiterpenic and aliphatic alcohols and these components can be formed by the oxidation or reduction during beer production. In general, these compounds are more soluble in water compared to the hydrocarbons because of the higher polarity of the molecule. ${ }^{6,7}$ Generally, myrcene, which is the most abundant component in hop essential oil, is undesirable in beer, while linalool and geraniol - both from an oxygen fraction 
present in lower concentrations than myrcene, present a pleasant aroma. The odour threshold is more important than the concentration level of a component in beer. ${ }^{11}$

The analytical approach to determine the volatile flavour-active compounds in beer is based on different solvent extraction techniques and separation by gas chromatography with flame ionization detection (GC-FID) or gas chromatography-mass spectrometry (GC-MS). ${ }^{12}$ A newer approach to determine the volatile aroma compound is based on a solvent-free extraction technique, head-space solid phase micro extraction (HS-SPME), ${ }_{13,8}$ head-space trap GC-MS analysis of hop essential oils ${ }^{14,15}$ and stir bar sorptive extraction. ${ }^{16}$

Much research has been done to investigate the complexity of the final flavour compounds in beer aroma, but in our study the dynamics of the transfer of hop essential oil components as well as the dynamics of the isomerization of alpha-acids were studied directly during process. The aim of this study was to explore the levels of hop essential oils and alpha-acids during short- and long-time kettle hopping. By preparing the first two beer types (A$\mathrm{B}$ ), we investigated the behaviour of hop essential oil components (HEOC) during short-time (A) and long-time (B) wort boiling. In preparing the second two types of beer, we investigated dry hopping techniques of beer aroma compounds originated from hops. We tried to determine the difference if hop is added at the beginning of fermentation $(C)$, or at the beginning of maturation (D).

\section{Experimental}

\section{1. Experimental Beer Brewing}

For $90 \mathrm{~L}$ of wort $100 \mathrm{~L}$ of water and $20 \mathrm{~kg}$ of Pilsner Malt (Castle Malt, Belgium) were used. The mashing process started at $52{ }^{\circ} \mathrm{C}$ for $30 \mathrm{~min}$, then the temperature was increased to $63{ }^{\circ} \mathrm{C}$ for $30 \mathrm{~min}$, the temperature was increased once more to $72{ }^{\circ} \mathrm{C}$ for $30 \mathrm{~min}$ and finally the temperature was increased to $76^{\circ} \mathrm{C}$ and held for $10 \mathrm{~min}$. After mashing and lautering the wort was divided into four parts, $1 \times 60 \mathrm{~L}$ and $2 \times 15 \mathrm{~L}$. For beers A (short time boiling) and B (long time boiling) the whole amount of hop was added at the beginning of the wort boiling and left it in for $60 \mathrm{~min}$. After that, the wort was divided in 2 equal parts $(30 \mathrm{~L})$. The second part of the wort continued with boiling for another $60 \mathrm{~min}$ (120 $\mathrm{min}$ in total). In each $30 \mathrm{~L}$ $250 \mathrm{~g}$ of hop cones were added. For beers $\mathrm{C}$ and $\mathrm{D}$ wort was boiling without hop in the same way as in the first two trials. In one $15 \mathrm{~L}$ fermentation tank $125 \mathrm{~g}$ of hop was added and left it until the end of six days of fermentation (beer C). In the second $15 \mathrm{~L}, 125 \mathrm{~g}$ of hop was added after the fermentation process, at the beginning of a two week maturation (beer D). Yeast strain used in fermentation process was Saflager W34/70 (Fermentis) $1 \mathrm{~g}$ per L. The duration of the fermentation was 5 days at $12^{\circ} \mathrm{C}$, while maturation take place at $2{ }^{\circ} \mathrm{C}$ for 2 weeks. After adding hops into boil- ing wort, samples were collected every $10 \mathrm{~min}$. During fermentation, samples were collected on each day of fermentation and during maturation, samples were collected every week of maturation.

\section{2. Beer Analyses}

Basic beer characteristics were measured. Determination of extract, alcohol and degree of fermentation were carried out according to the MEBAK II, method 2.10.4. ${ }^{17}$ Determination of $\mathrm{pH}$ value was carried out according to the Analytica EBC, method 9.35. ${ }^{18}$ Bitterness of beer was measured according to the Analytica EBC, method 9.8. ${ }^{197}$ Measurement of $\mathrm{CO}_{2}$ was carried out according to the Analytica EBC, method 9.28.3 $3^{20}$ and the determination of beer colour was carried out according to the Analytica EBC, method 9.6. ${ }^{21}$

\section{3. Analytical Determination of Hop Metabolites}

Determination of the content of hop essential oil was carried out according to Analytica EBC, method 7.10, ${ }^{22}$ using standard steam distillation. The determination of hop essential oil components was carried out according to the Analytica EBC, method $7.12^{23}$ using GC-FID. The determination of alpha-acids was carried out according to the Analytica EBC, method 7.4. ${ }^{24}$

\section{4. Determination of Hop Essential Oil Components (HEOC) in Beer}

For the hop essential oil component analysis in beer, an Agilent 6890 GC, equipped with FID detector (Agilent Technologies, USA) was used. The determination of essential oils was performed on a $60 \mathrm{~m} \times 0.32 \mathrm{~mm} \times 0.25 \mu \mathrm{m}$ DBWax capillary column (Agilent Technologies, USA) according to the MEBAK, method $2.23 .6^{25}$ with some modifications, where the aroma compounds are driven out of the sample by steam distillation. The extraction of aroma compounds was performed by shaking $80 \mathrm{~mL}$ of distillate in $100 \mathrm{~mL}$ glass centrifuge tubes with $1 \mathrm{~mL}$ dichloromethane (Sigma-Aldrich, USA). Helium 5.0 was used as a carrier gas with a

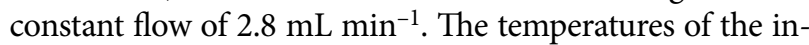
jector and detector were set to $250^{\circ} \mathrm{C}$. The temperature program started at $60^{\circ} \mathrm{C}$ for $4 \mathrm{~min}$, then increased by $5^{\circ} \mathrm{C} \mathrm{min}{ }^{-1}$ to $220^{\circ} \mathrm{C}$ and was held at $220^{\circ} \mathrm{C}$ for $30 \mathrm{~min}$, then increased by $20^{\circ} \mathrm{C} \mathrm{min}-1$ to $240{ }^{\circ} \mathrm{C}$ and held for $5 \mathrm{~min}$ at $240{ }^{\circ} \mathrm{C}$. The sample injection volume was $4 \mu \mathrm{L}$. Methyl heptanoate (Sigma-Aldrich, USA) was used as an internal standard. Identifications and quantifications of all investigated compounds presented in Table 1 were performed using standards purchased through Sigma-Aldrich, USA. For all measured parameters, the repeatability, accuracy and linearity for analytes were determined. RSDs for repeatability were from 1.3 to $1.9 \%$. All measurements were done in duplicate. 
Table 1: Composition of Dana essential oil

\begin{tabular}{|c|c|}
\hline Essential oil component & $\%$ in hop oil \\
\hline Methyl hexanoate & 0.4 \\
\hline a-Pinene & 0.2 \\
\hline Myrcene & 37.5 \\
\hline Linalool & 1.1 \\
\hline Borneol & 0.1 \\
\hline a-Terpineole & 0.4 \\
\hline Methyl nonanoate & 0.2 \\
\hline Nerol & 0.3 \\
\hline$\beta$-Citronellol & 0.3 \\
\hline Geraniol & 0.5 \\
\hline Methyl caprate & 1.0 \\
\hline Neryl acetate & 0.2 \\
\hline Geranyl acetate & 0.4 \\
\hline$\beta$-Cariophyllene & 9.4 \\
\hline a-Humulene & 21.1 \\
\hline$\beta$-Farnesene & 5.1 \\
\hline Tridecanone & 0.8 \\
\hline Geranyl iso-butyrate & 1.0 \\
\hline Cariophylene oxide & 0.9 \\
\hline Farnezol & 0.2 \\
\hline Limonene & 0.3 \\
\hline
\end{tabular}

\section{5. Alpha-Acids and Iso-Alpha-Acids Determination}

To determine alpha-acids and iso-alpha-acids in wort and beer, samples were taken and frozen at $-20{ }^{\circ} \mathrm{C}$ until analysis. Prior to analysis, samples were warmed to room temperature and centrifuged at $3000 \mathrm{rpm}$ for $15 \mathrm{~min}$ in Heraeus Biofuge Primo (Switzerland) centrifuge. The clear upper phase was filtered through $0.45 \mu \mathrm{m}$ PET filters into $2 \mathrm{~mL}$ glass vials. Injection of $2 \mu \mathrm{L}$ was made with an auto sampler of an Agilent 1200 HPLC chromatograph, using HPLC grade methanol (Merck, Germany), distilled water and 85\% orto-phosphoric acid (Sigma Aldrich, USA) in a ratio of 77.5: 21: 0.9 as a mobile phase. Separation was performed on a $150 \mathrm{~mm}$ long Nucleodur C18 Column (Macherey Nagel, Germany). Iso-alpha-acids were recorded at wavelength 270 $\mathrm{nm}$, while alpha-acids were recorded at $314 \mathrm{~nm}$.

\section{Results and Discussion}

In each type of beer brewed, the same amount $\left(\mathrm{g} \mathrm{L}^{-1}\right)$ of the traditional Slovenian variety, Dana, with the al- pha-acids content $9.0 \%$ and $1.9 \mathrm{~mL}$ of hop essential oil on $100 \mathrm{~g}$ of dried hop was used. Basic beer specifications of all investigated beer types are presented in Table 2. Data consists of extract, alcohol, degree of fermentation, $\mathrm{pH}$, bitterness, content of $\mathrm{CO}_{2}$ and content of iso-alpha-acids.

\section{1. Isomerization of Alpha-Acids}

The content of iso-alpha-acids is the sum of all three peaks of isomerized analogues of alpha-acids: iso-cohumulone $\left(t_{\mathrm{R}}=4.19 \mathrm{~min}\right)$, iso-adhumulone $\left(t_{\mathrm{R}}=4.97 \mathrm{~min}\right)$ and iso-humulone ( $\left.t_{\mathrm{R}}=5.42 \mathrm{~min}\right)$. In brewing science, the iso-alpha-acids are expressed as the sum of all three components, because for brewers, the sum value is relevant. The content of alpha-acids is the sum of cohumulone $\left(t_{\mathrm{R}}=\right.$ $8.39 \mathrm{~min})$ and $\mathrm{n}+$ adhumulone $\left(t_{\mathrm{R}}=10.70 \mathrm{~min}\right)$. In Figure 1 where the dynamics of isomerization of alpha-acids for beer type $B$ are presented, one can see a high isomerization rate in the first $30 \mathrm{~min}$.

The highest utilization of $18.1 \%$ was achieved after $100 \mathrm{~min}$ of boiling. Isomerization yield was calculated as the ratio of actual mass concentration of iso-alpha-acids in beer, divided by the know content of alpha-acids in hop that was added into wort. Each sample taken later had smaller concentrations of iso-alpha-acids and smaller concentrations of alpha-acids. There was also a small part (1.6\% of total alpha-acids added in wort) of alpha-acids that remained un-isomerized. This is a sign that longer boiling causes further degradation of iso-alpha acids. During fermentation we can see the concentration of iso-alpha-acids decreasing but a small increase in concentration was noticed on the last, fifth day of fermentation. Concentration during the maturation process increased to the final isomerization yield of $14.6 \%$. The rise of IAA is occurred during maturation, where all bioprocess are finished, all the components reacts between each other's and beer gets its flavour and aroma. ${ }^{6}$ The pattern was the same (not shown) in beer type $\mathrm{A}$, with one difference. The maximum isomerization yield was achieved at the end of boiling for $60 \mathrm{~min}$, but after this time there is a part ( $4.6 \%$ of total alpha-acids added in wort) of alpha-acids that remain un-isomerized. Again, the concentrations decreased during fermentation and slightly increased during the maturation process.

In beer $\mathrm{C}$, the concentration of iso-alpha-acids decreased every day until the final isomerization yield was below 1\% (Figure 2).

Table 2. Basic beer characteristics for each beer type.

\begin{tabular}{lccccccc}
\hline $\begin{array}{l}\text { Beer } \\
\text { type }\end{array}$ & $\begin{array}{c}\text { Extract } \\
\mathbf{( \% )}\end{array}$ & $\begin{array}{c}\text { Alcohol } \\
(\mathbf{v o l . ~ \% )}\end{array}$ & $\begin{array}{c}\text { Degree of } \\
\text { fermentation (\%) }\end{array}$ & $\mathbf{p H}$ & $\begin{array}{c}\text { Bitterness } \\
(\mathbf{I B U})\end{array}$ & $\begin{array}{c}\mathbf{C O}_{\mathbf{2}} \\
\left(\mathbf{g ~ L}^{-\mathbf{1}}\right)\end{array}$ & $\begin{array}{c}\text { Iso-alpha-acids } \\
\left(\mathbf{m g ~ L}^{-\mathbf{1}}\right)\end{array}$ \\
\hline A & 11.8 & 5.1 & 66.2 & 4.7 & 112 & 3.0 & 98 \\
B & 12.6 & 6.1 & 67.1 & 4.8 & 120 & 3.1 & 110 \\
C & 11.3 & 5.2 & 68.8 & 4.7 & 14 & 4.7 & 6 \\
D & 11.4 & 5.2 & 69.1 & 4.7 & 8 & 4.8 & 6 \\
\hline
\end{tabular}




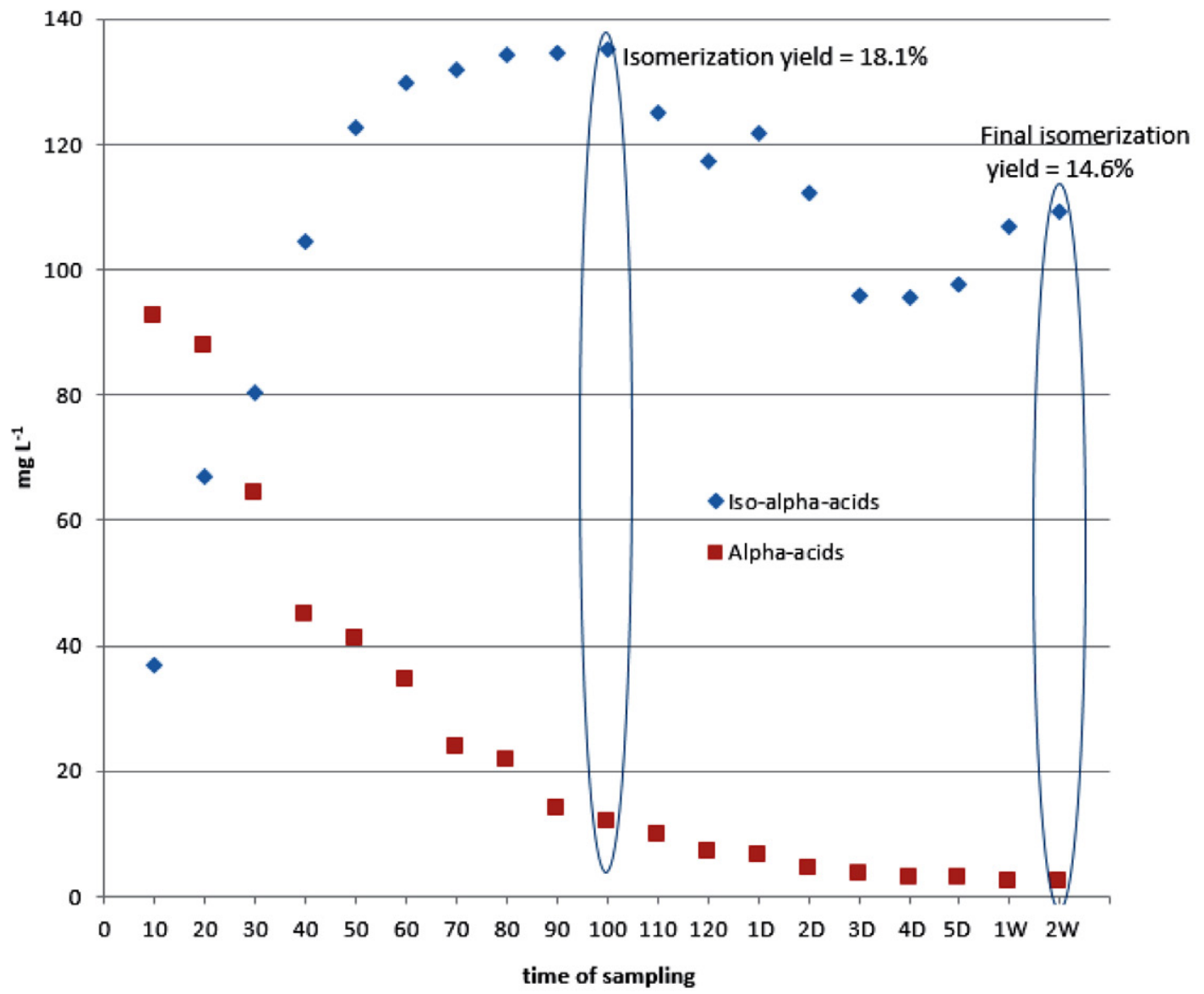

Figure 1: Dynamic of isomerization of alpha-acids in beer B. Sampling was made every 10 min during boiling, every day of fermentation and every week of maturation.

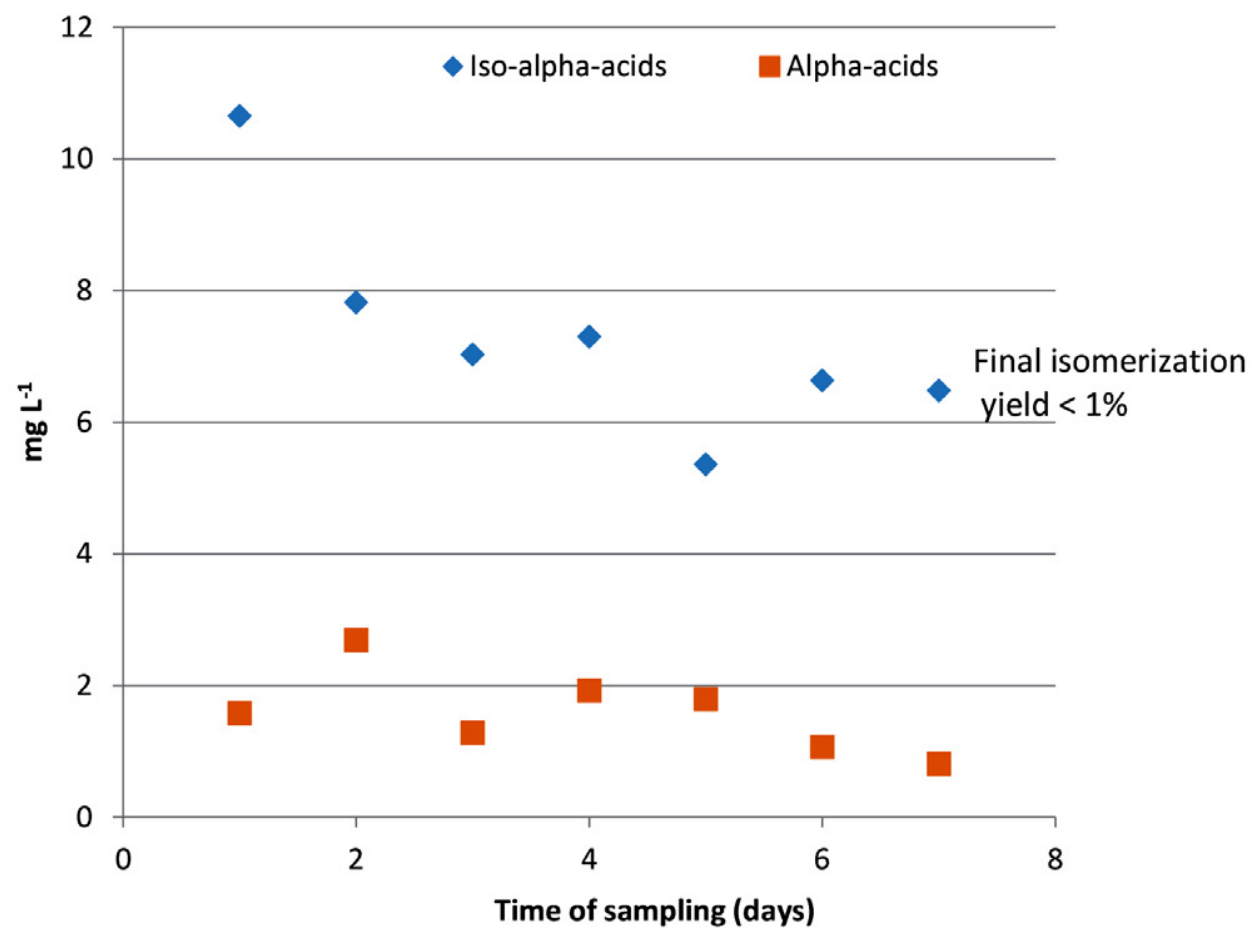

Figure 2. Dynamic of isomerization of alpha-acids in beer C. 
The alpha-acid content in the beer was approximately $2 \mathrm{mg} \mathrm{L}^{-1}$ from the beginning of the process to the end of fifth day. The cause of low isomerization yield was the low temperature of the process. The cause is also limited solubility of alpha-acids in the wort and further losses of iso-alpha-acids post wort boiling; the absorption of trub and because of losses during clarification. ${ }^{26-29}$ Knowledge of the utilization value of iso-alpha-acids for each brewery is of crucial importance for brewers to achieve a desired level of bitterness in beer. In Table 3, where the dynamics
Table 3. Dynamics of isomerization in beer D

\begin{tabular}{lcc}
\hline $\begin{array}{l}\text { Time of } \\
\text { sampling }\end{array}$ & $\begin{array}{c}\text { Alpha-acids } \\
\left(\mathbf{m g ~ L}^{-\mathbf{1}}\right)\end{array}$ & $\begin{array}{r}\text { Iso-alpha- } \\
\text { acids }\left(\mathbf{m g ~ L}^{-\mathbf{1}}\right)\end{array}$ \\
\hline After 1 week of maturation & 7.2 & 5.8 \\
After 2 weeks of maturation & 8.6 & 6.0 \\
\hline
\end{tabular}

of isomerization in beer $\mathrm{D}$ is presented, one can see that the concentrations of alpha-acids are slightly higher than

a)

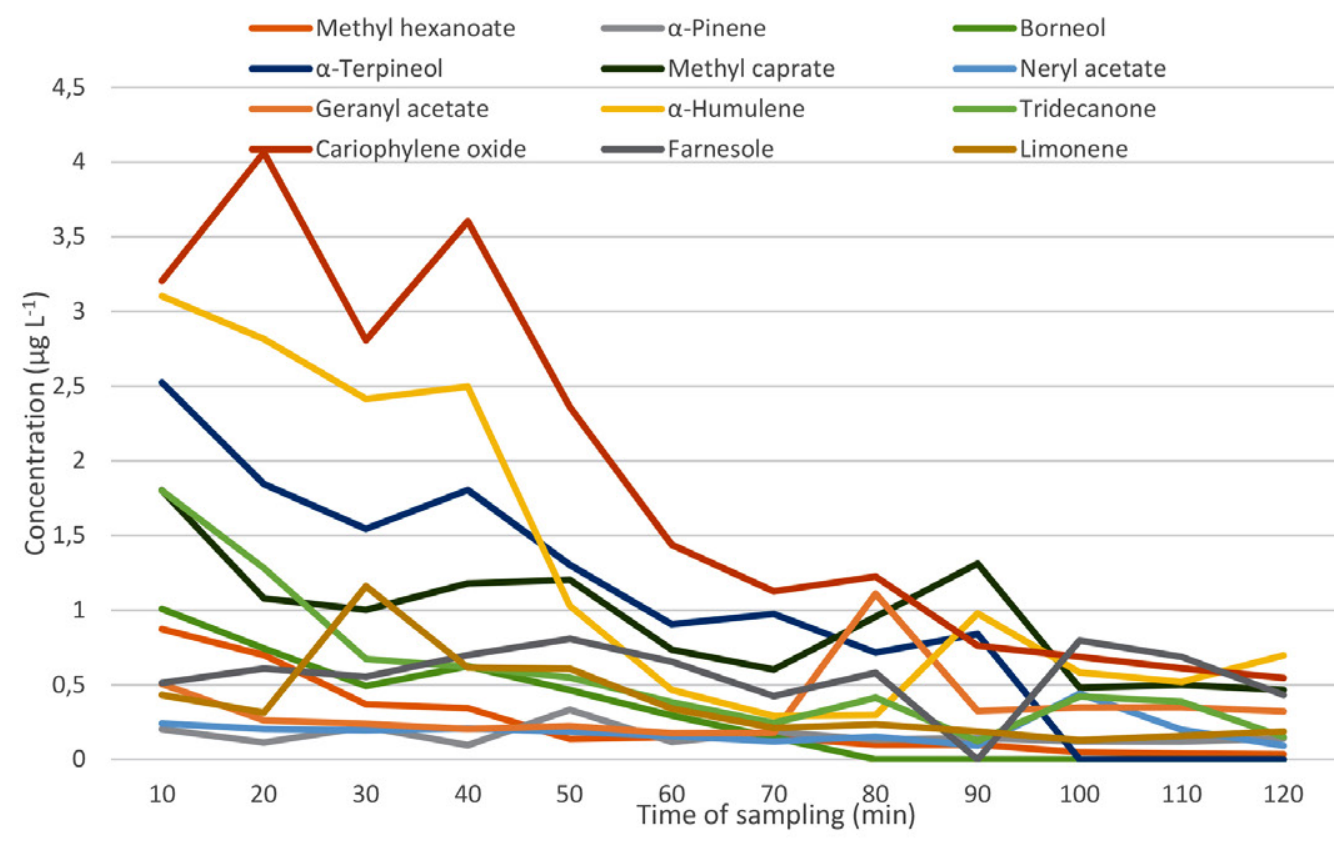

b)

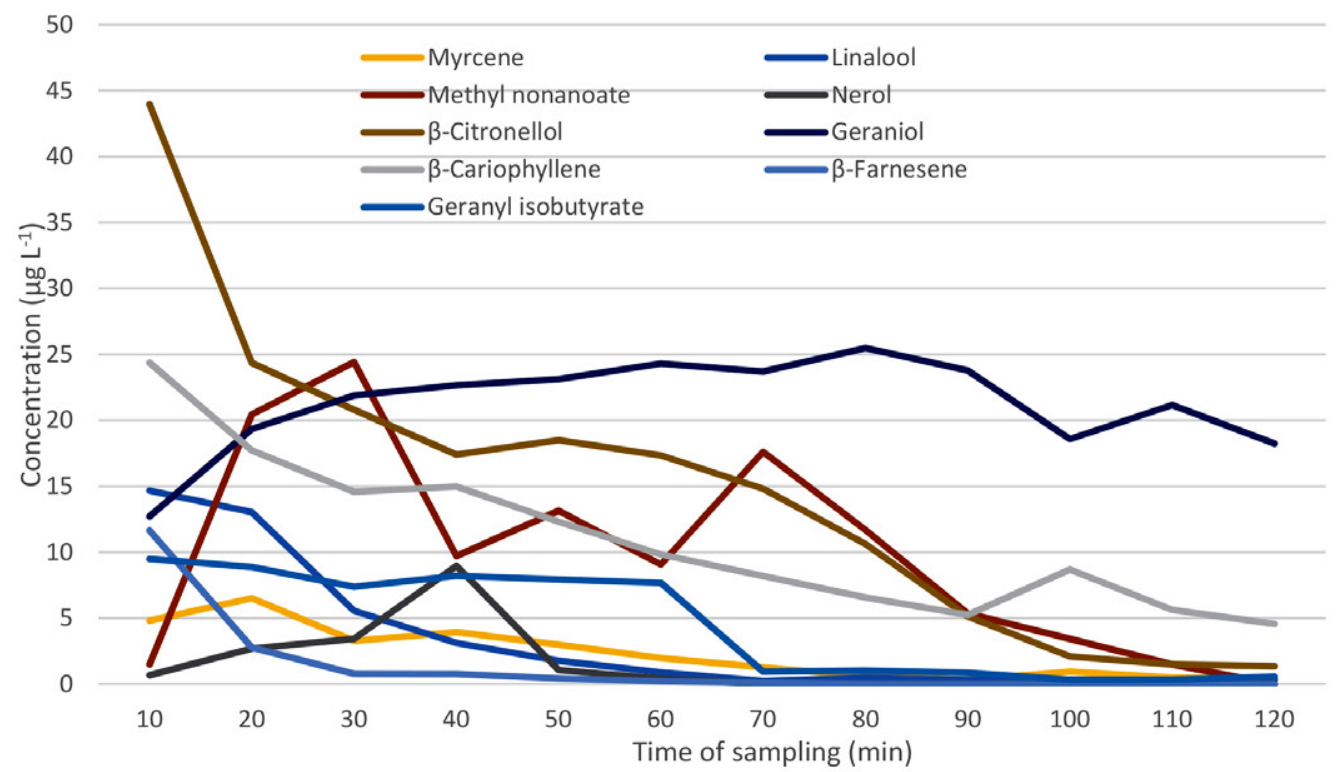

Figure 3a and 3b. Transition of hop essential oil components during wort boiling. 
the concentrations of iso-alpha-acids. Both concentrations are very low, as the isomerization process depends on the temperature of the medium.

\section{2. Determination of the Transition of HEOC in Beer}

The most abundant components of Dana essential oils were focused on. These components with their relative abundance in hop are presented in Table 1. Concentrations of investigated HEOC at the beginning of the hop- ping process and at the end of the experiment are presented in Table 3. Concentrations of HEOC during wort boiling in beer types A and B (first 60 min for beers A + B and next 60 min for beer $B$ ) decreased at different rates (Figures $3 \mathrm{a}$ and $3 \mathrm{~b}$ ).

Some were decreased to the values $<$ LOD. The exception is geraniol, where a small increase in concentration is noticed. It is important to know that these are not the final concentrations in beer. The literature states that later in the fermentation or maturation process concentrations of some HEOC can increase, because of thermal re-

a)

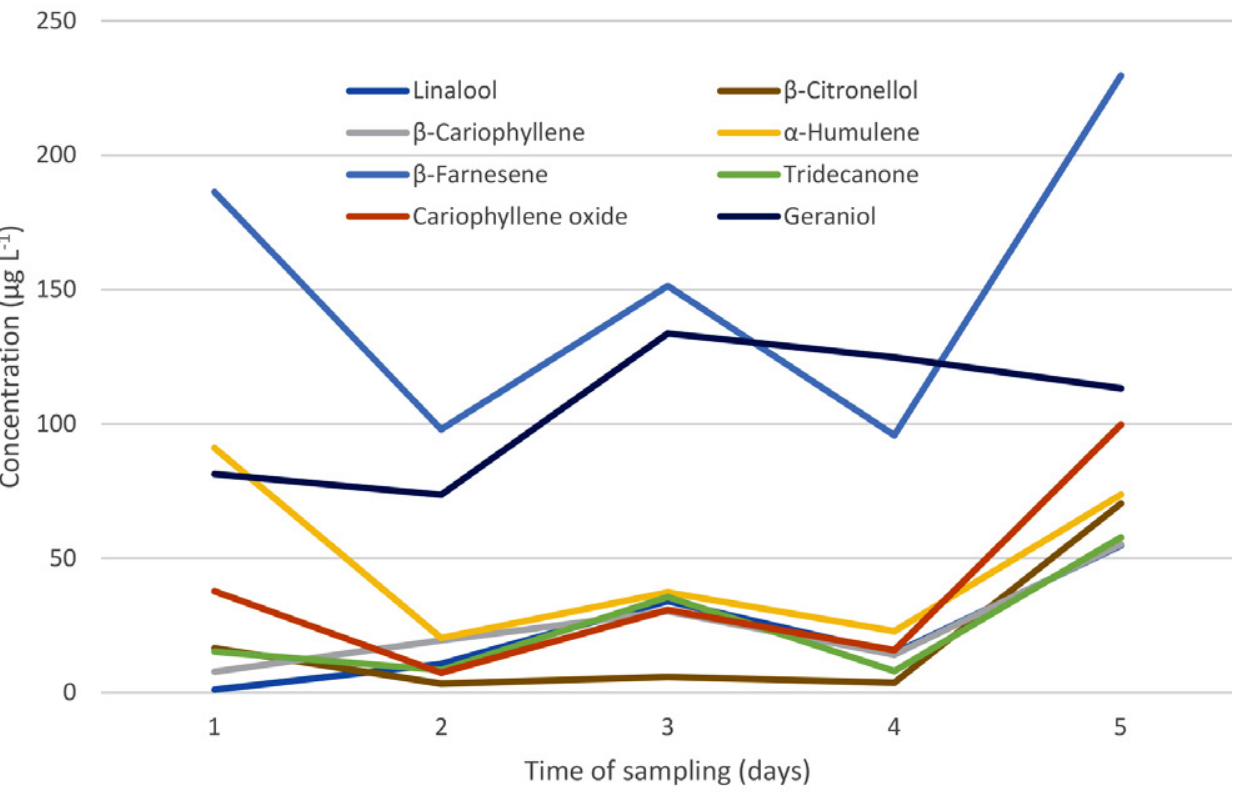

b)

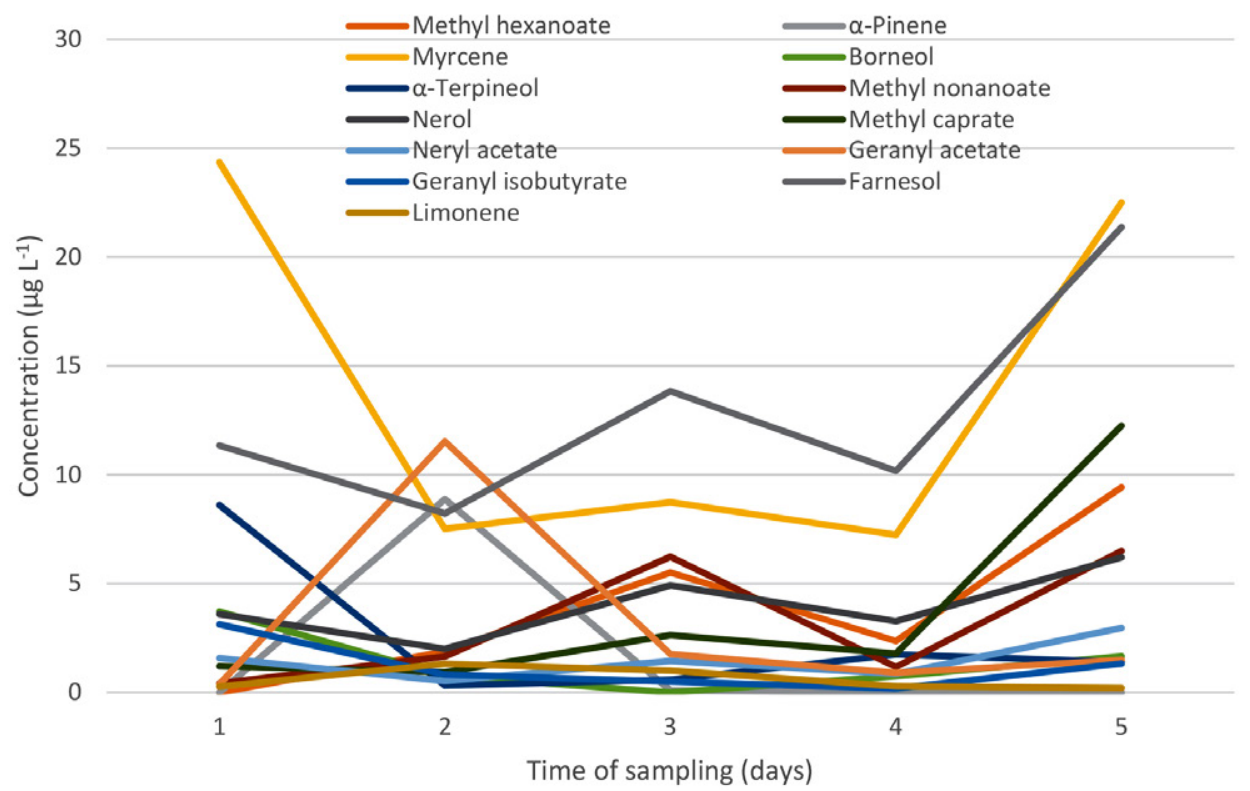

Figure $4 a$ and $4 b$. Transition of hop essential oil components during fermentation. 
actions or by biotransformation processes such as oxidation, reductions, isomerization or hydrolysis of volatiles that occur in beer brewing. ${ }^{30-35}$ Myrcene and $\alpha$-humulene, which belong to the terpene hydrocarbon fraction of essential oils, are hydrophobic and would not pass from the hops through to the finished beer during the brewing process. On the other hand, hydrophilic terpene alcohols, such as linalool, are easier to retain in the beer..$^{30,31}$ Due to evaporation during wort boiling, myrcene, although it is the most common component in essential oils, does not contribute to the beer aroma because the concentrations are normally far below the odour threshold level..$^{32}$ In beer $\mathrm{C}$ we observed the transition of HEOC during fermentation (Figure $4 \mathrm{a}$ and $4 \mathrm{~b}$ ).

In general, concentrations of HEOC begin high, and then some fluctuation in concentrations is observed, until the last day of fermentation when the HEOC are again in the same range as at the beginning. One of the main reasons for such fluctuations in concentrations during dry hopping, which seems to be simple, but from a physicochemical point of view dry hopping is very complex and complicated, is not just extraction time and amount of hops but also the presence of yeast cells and carbon dioxide which can wash out the essential components from beer. ${ }^{6,7}$

It is interesting, that concentrations of limonene, a-terpineole, neryl acetate and geranyl-iso-butyrate remain almost the same as they were after the first day of dry hopping. Concentration of linalool increases around 50 times. The concentrations of HOEC in beer $\mathrm{C}$ are generally higher than in both "kettle hopped" beers A and B. In beer $\mathrm{D}$, where hop was added only at the beginning of the maturation process, two types of HEOC dynamics are observed. In Table 4 , some concentrations decrease with time while some of the concentrations increase.

Some concentrations are higher than in beer $\mathrm{C}$. One of the reasons is a low temperature during the maturation process and live environment in the fermentation process. Beside extraction of HEOC in wort or beer, chemical reactions between some components can lead to an increase of concentrations. Linalool can come from nerol or geraniol, and $\beta$-citronellol can come from geraniol. Linalool could be also cyclized to $\alpha$-terpineol. ${ }^{31,33}$ Although linalool is not abundant in hops, it's contribution to beer aroma is high because of its very low odour threshold value of $2.2 \mu \mathrm{g}$ $\mathrm{L}^{-1} \cdot{ }^{34}$ Henke et al. also reported that concentrations of geraniol increase during fermentation, which is in line with our results. ${ }^{35}$

\section{Conclusions}

From this experiment, it can be concluded that the optimal time of hopping to achieve high bitterness is no longer, than $100 \mathrm{~min}$. Dry hopping also effects beer bitterness, but the isomerization rates are very low, and consequently higher concentrations of un-isomerized alpha-acids were detected. During brewing, severe losses, oh hop essential oils occur by evaporation in the hot part

Table 4. Concentrations of hop essential oil components in beer types A-D (LOD $\left.=0.1 \mu \mathrm{g} \mathrm{L}^{-1}\right)$

\begin{tabular}{|c|c|c|c|c|c|c|c|c|}
\hline & \multicolumn{2}{|c|}{$\mathbf{A}$} & \multicolumn{2}{|c|}{ B } & \multicolumn{2}{|c|}{ C } & \multicolumn{2}{|c|}{ D } \\
\hline & $\begin{array}{c}\text { Start } \\
{\left[\mu \mathrm{g} \mathrm{L}^{-1}\right]}\end{array}$ & $\begin{array}{c}\text { Final } \\
{\left[\mu \mathrm{g} \mathrm{L^{-1 } ]}\right.}\end{array}$ & $\begin{array}{c}\text { Start } \\
{\left[\mu \mathrm{g} \mathrm{L}^{-1}\right]}\end{array}$ & $\begin{array}{c}\text { Final } \\
{\left[\mu \mathrm{g} \mathrm{L}^{-1}\right]}\end{array}$ & $\begin{array}{c}\text { Start } \\
{\left[\mu \mathrm{g} \mathrm{L}^{-1}\right]}\end{array}$ & $\begin{array}{c}\text { Final } \\
{\left[\mu \mathrm{g} \mathrm{L^{-1 } ]}\right.}\end{array}$ & $\begin{array}{r}\text { Start } \\
{\left[\mu \mathrm{g} \mathrm{L}^{-1}\right]}\end{array}$ & $\begin{array}{c}\text { Final } \\
{\left[\mu \mathrm{g} \mathrm{L}^{-1}\right]}\end{array}$ \\
\hline Methyl hexanoate & $0.9 \pm 0.1$ & $0.4 \pm 0.1$ & $0.9 \pm 0.1$ & $0.4 \pm 0.1$ & $<\mathrm{LOD}$ & $9.4 \pm 0.2$ & $4.2 \pm 0.1$ & $2.4 \pm 0.1$ \\
\hline a-Pinene & $0.2 \pm 0.1$ & $0.2 \pm 0.1$ & $0.2 \pm 0.1$ & $0.1 \pm 0.1$ & $<\mathrm{LOD}$ & $<\mathrm{LOD}$ & $<\mathrm{LOD}$ & $<\mathrm{LOD}$ \\
\hline Myrcene & $4.8 \pm 0.1$ & $1.9 \pm 0.1$ & $4.8 \pm 0.1$ & $0.4 \pm 0.1$ & $24.3 \pm 0.3$ & $22.5 \pm 0.3$ & $0.6 \pm 0.1$ & $1.71 \pm 0.1$ \\
\hline Linalool & $14.6 \pm 0.2$ & $0.9 \pm 0.1$ & $14.6 \pm 0.2$ & $0.3 \pm 0.1$ & $1.1 \pm 0.1$ & $54.7 \pm 0.8$ & $19.7 \pm 0.3$ & $28.2 \pm 0.3$ \\
\hline Borneol & $1.0 \pm 0.1$ & $0.3 \pm 0.1$ & $1.0 \pm 0.1$ & $<$ LOD & $3.7 \pm 0.1$ & $1.7 \pm 0.1$ & $0.3 \pm 0.1$ & $0.3 \pm 0.1$ \\
\hline a-Terpineole & $2.5 \pm 0.1$ & $0.9 \pm 0.1$ & $2.5 \pm 0.1$ & $<$ LOD & $8.6 \pm 0.2$ & $1.4 \pm 0.1$ & $0.4 \pm 0.1$ & $0.6 \pm 0.1$ \\
\hline Methyl nonanoate & $1.5 \pm 0.1$ & $9.0 \pm 0.2$ & $1.5 \pm 0.1$ & $<\mathrm{LOD}$ & $0.4 \pm 0.1$ & $6.5 \pm 0.1$ & $5.7 \pm 0.1$ & $14.9 \pm 0.2$ \\
\hline Nerol & $0.7 \pm 0.1$ & $0.4 \pm 0.1$ & $0.7 \pm 0.1$ & $<$ LOD & $3.6 \pm 0.1$ & $6.2 \pm 0.1$ & $2.9 \pm 0.1$ & $11.3 \pm 0.2$ \\
\hline$\beta$-Citronellol & $43.9 \pm 0.7$ & $17.3 \pm 0.4$ & $43.9 \pm 0.7$ & $1.3 \pm 0.1$ & $16.5 \pm 0.3$ & $70.3 \pm 1.1$ & $1.3 \pm 0.1$ & $0.7 \pm 0.1$ \\
\hline Geraniol & $12.7 \pm 0.2$ & $24.3 \pm 1.0$ & $12.7 \pm 0.2$ & $18.2 \pm 0.3$ & $81.3 \pm 1.3$ & $113.2 \pm 1.8$ & $4.0 \pm 0.2$ & $26.9 \pm 0.4$ \\
\hline Methyl Caprate & $1.8 \pm 0.1$ & $0.7 \pm 0.1$ & $1.8 \pm 0.1$ & $0.5 \pm 0.1$ & $1.2 \pm 0.1$ & $12.2 \pm 0.2$ & $2.8 \pm 0.1$ & $1.7 \pm 0.1$ \\
\hline Neryl acetate & $0.2 \pm 0.1$ & $0.1 \pm 0.1$ & $0.2 \pm 0.1$ & $1.0 \pm 0.1$ & $1.6 \pm 0.1$ & $3.0 \pm 0.1$ & $1.4 \pm 0.1$ & $0.9 \pm 0.1$ \\
\hline Geranyl acetate & $0.5 \pm 0.1$ & $0.2 \pm 0.1$ & $0.5 \pm 0.1$ & $0.3 \pm 0.1$ & $0.4 \pm 0.1$ & $1.5 \pm 0.1$ & $1.1 \pm 0.1$ & $38.2 \pm 0.6$ \\
\hline$\beta$-Cariophyllene & $24.4 \pm 0.3$ & $9.8 \pm 0.2$ & $24.4 \pm 0.3$ & $4.6 \pm 0.1$ & $7.8 \pm 0.1$ & $55.2 \pm 0.7$ & $5.0 \pm 0.1$ & $2.3 \pm 0.1$ \\
\hline a-Humulene & $3.1 \pm 0.1$ & $0.4 \pm 0.1$ & $3.1 \pm 0.1$ & $0.6 \pm 0.1$ & $91.1 \pm 1.4$ & $73.7 \pm 1.1$ & $1.7 \pm 0.1$ & $36.5 \pm 0.6$ \\
\hline$\beta$-Farnesene & $11.6 \pm 0.2$ & $0.2 \pm 0.01$ & $11.6 \pm 0.2$ & $<\mathrm{LOD}$ & $186.1 \pm 2.7$ & $229.6 \pm 3.2$ & $10.7 \pm 0.2$ & $39.4 \pm 0.6$ \\
\hline Tridecanone & $1.8 \pm 0.1$ & $0.4 \pm 0.1$ & $1.8 \pm 0.1$ & $0.1 \pm 0.1$ & $15.2 \pm 0.3$ & $57.8 \pm 1.0$ & $10.6 \pm 0.2$ & $31.5 \pm 0.5$ \\
\hline Geranyl iso-butyrate & $9.5 \pm 0.2$ & $7.7 \pm 0.2$ & $9.5 \pm 0.2$ & $0.5 \pm 0.1$ & $3.1 \pm 0.1$ & $1.3 \pm 0.1$ & $5.7 \pm 0.1$ & $<$ LOD \\
\hline Cariophylene oxid & $3.2 \pm 0.1$ & $1.4 \pm 0.1$ & $3.2 \pm 0.1$ & $0.5 \pm 0.3$ & $37.7 \pm 0.7$ & $99.7 \pm 1.8$ & $8.6 \pm 0.1$ & $17.6 \pm 0.3$ \\
\hline Farnezol & $0.5 \pm 0.1$ & $0.6 \pm 0.1$ & $0.5 \pm 0.1$ & $18.6 \pm 0.3$ & $11.3 \pm 0.2$ & $21.4 \pm 0.4$ & $4.7 \pm 0.1$ & $3.6 \pm 0.1$ \\
\hline Limonene & $0.4 \pm 0.1$ & $0.3 \pm 0.1$ & $0.4 \pm 0.1$ & $0.2 \pm 0.1$ & $0.3 \pm 0.1$ & $0.2 \pm 0 . .1$ & $0.1 \pm 0.1$ & $3.1 \pm 0.1$ \\
\hline
\end{tabular}


of the process. Losses in the cold part of beer production are mainly consequence of washing out aroma compounds by carbon dioxide and adsorption of the aroma compounds on the yeast cells. Nevertheless, oxidation and reaction between aroma compounds can lead to rise of concentration of these compounds. Dry hopping does not result in increased aroma intensity in all cases.

\section{Funding Sources}

This work was financially supported by the Slovenian Research Agency by grant 020-2/2011-3.

\author{
Abbreviations \\ HEOC - hop essential oil components, $t_{\mathrm{R}}$ - retention \\ time
}

\section{References}

1. C. Almaguer, C. Schönberger, M. Gastl, K. E. Arendt, T. Becker, Humulus lupulus - a story that begs to be told. A review, J. Inst. Brew. 2014, 120, 289-314. DOI:10.1002/jib.160

2. K. Štěrba, P. Čejka, J. Čulík, M. Jurková, K. Krofta, M. Pavlovič, A. Mikyška, J. Olšovská, Determination of Linalool in different hop varieties using a new method based on fluidized - bed extraction with gas chromatographic mass spectrometric detection, J. Am. Soc. Brew. Chem. 2015, 73, 151-158.

DOI:10.1094/ASBCJ-2015-0406-01

3. M. G. Malowicki, T. H. Shellhammer, Isomerization and degradation kinetics of hop (Humulus lupulus) acids in a model wort-boiling system, J. Agric. Food Chem. 2005, 53 44344439. DOI: $10.1021 /$ jf0481296

4. T. Inui, F. Tsuchiya, M. Ishimaru, K. Oka, H. Komura, Different beers with different hops. Relevant compounds for their aroma characteristics, J. Agric. Food Chem. 2013, 61, 4758-64. DOI:10.1021/jf3053737

5. M. Schnaitter, A. Kell, H. Kollmannsberger, F. Schüll, M. Gastl, T. Becker, Scale-up of dry hopping trials: importance of scale for aroma and taste perceptions, Chem. Ing. Tech, 2016, 88, 1955-1965. DOI:10.1002/cite.201600040

6. N. Rettberg, M. Biendl, L. A. Garbe, Hop Aroma and Hoppy Beer Flavour: Chemical Background and Analytical Tools-A review, J. Am. Soc. Brew. Chem. 2018, 76, 151-158.

DOI:10.1080/03610470.2017.1402574

7. L. Jelínek, M. Karabin, J. Müllerová, P. Dostálek, The secret of dry hopped beers-Review. Kvasny Prum. 2018, 64, 287-296. DOI:10.18832/kp201836

8. J. Dennenlöhr, S. Thörner, A. Manowski, N. Rettberg, Analysis of selected Hop Aroma Compounds in Commercial Lager and Craft Beers Using HS-SPME-GC-MS/MS. J. Am. Soc. Brew. Chem. 2019.

DOI:10.1080/03610470.2019.1668223

9. M. T. Roberts, J. P. Dufour, A. C. Lewis, Application of comprehensive multidimensional gas chromatography combined with time-of-flight mass spectrometry (GC/GC-TOFMS) for high resolution analysis of hop essential oil, J. Sep. Sci. 2004, 27, 473-478. DOI:10.1002/jssc.200301669

10. G. A. Fix, Wort Boiling in Principles of Brewing Science - a Study of Serious Brewing Issues $2^{\text {nd }}$ ed., Brewers Publications, Boulder, USA, 1999, pp. 53-78.

11. C. W. Bamforth, Science principles of malting and brewing, American Society of Brewing Chemists, St. Paul, 2006.

12. M. Kovačevič, M. Kač, Determination and verification of hop varieties by analysis of hop essential oils, Food Chem. 2002, 77, 489-494. DOI:10.1016/S0308-8146(02)00114-0

13. J. Hrivňák, D. Smogrovičová, P. Nádaský , J. Lakatošová, Determination of beer aroma compounds using headspace solid-phase microcolumn extraction, Talanta. 2010, 83, 294296. DOI:10.1016/j.talanta.2010.08.041

14. G. C. da Silva, A. A. S. da Silva, L. S. N. Da Silva, R. L. D. O. Godoy, L.C. Nogouira, S.L. Quitério, R.S.L. Raices. Method development by GC-ECD and HS-SPME-GC-MS for beer volatile analysis, Food Chem. 2015, 167, 71-77.

DOI:10.1016/j.foodchem.2014.06.033

15. C. Schmidt, M. Biendl, Headspace Trap GC-MS analysis of hop aroma compounds in beer, Brewing Sci. 2016, 69, 9-15.

16. T. Horak, J. Culik, V. Kellner, P. Čejka, D. Hašková, M. Jurková, J. Dvořák, Determination of selected beer flavours: Comparison of a stir bar sorptive extraction and a steam distillation procedure, J. Ins. Brew. 2011, 117, 617-621.

DOI:10.1002/j.2050-0416.2011.tb00512.x

17. Destillationsanalyse (Referenzmethode - EBC - Methode), Brautechnischen Aanalysenmethoden Band II, 4. Auflage, MEBAK, Freising-Weihenstephan, 2002, 76-78.

18. European Brewery Convention, Analytica EBC, section 9 Beer, method 9.35, Analytica EBC, Fachverlag Hans Carl, Nürnberg, 2004.

19. European Brewery Convention, Analytica EBC, section 9 - Beer, method 9.8, Analytica EBC, Fachverlag Hans Carl, Nürnberg, Germany 2004.

20. European Brewery Convention, Analytica EBC, section 9 Beer, method 9.28.3, Analytica EBC, Fachverlag Hans Carl, Nürnberg, 2007.

21. European Brewery Convention, Analytica EBC, section 9 - Beer, Method 9.6, Analytica EBC, Fachverlag Hans Carl, Nürnberg, Germany, 2000.

22. European Brewery Convention, Analytica EBC, section 7 Hops, Method 7.10, Fachverlag Hans Carl GmbH, Nürnberg, Germany, 2002.

23. European Brewery Convention, Analytica EBC, section 7 Hops, Method 7.12, Fachverlag Hans Carl GmbH, Nürnberg, Germany, 2006.

24. European Brewery Convention, Analytica EBC, section 7 Hops, Method 7.4, Fachverlag Hans Carl GmbH, Nürnberg, Germany, 2000.

25. Determination of Steam-volatile Aroma Compounds in Beer, method 2.23.6, MEBAK Wort, Beer, Beer-based Beverages, MEBAK, Freising, 2013, pp. $405-412$.

26. B. Jaskula, P. Kafarski, G. Aerts, L. De Cooman, A kinetic study of isomeriazion of Hop-acids, J. Agric. Food Chem. 2008, 56, 6408-6415. DOI:10.1021/jf8004965 
27. Y. Huang, J. Tippmann, T. Becker, Kinetic modelling of hop acids during wort boiling. Int. J. Biosci. Biochem. Bioinforma. 2013, 3, 47-52.

28. S. Kappler, M. Krahl, C. Geissinger, T. Becker, M. Krottenhaler, Degradation of Iso- $\alpha$-acids during wort boiling, J. Ins. Brew. 2010, 116, 332-338.

DOI:10.1002/j.2050-0416.2010.tb00783.x

29. B. Jaskula Goiris, G. Aerts, L. De Cooman, Hop a-acids isomerization and utilisation: an experimental review, Cerevisia. 2010, 6, 57-70. DOI:10.1016/j.cervis.2010.09.004

30. T. Kishimoto, A. Wanikawa, K. Kono, K. Shibata, Comparison of the Odor-Active Compounds in Unhopped Beer and Beers Hopped with Different Hop Varieties, J. Agric. Food Chem. 2006, 54, 8855-8861. DOI:10.1021/jf061342c

31. K. Takoi, K. Koie, Y. Itoga, Y. Katayama, M. Shimase, Y. Nakayama, J. Watari, Biotransformation of Hop-Derived Monoterpene Alcohols by Lager Yeast and Their Contribution to the Flavor of Hopped Beer, J. Agric. Food Chem. 2010, 58, 5050-5058. DOI:10.1021/jf1000524
32. M. Coelhan, A. Aberl, Determination of Volatile Compounds in Different Hop Varieties by Headspace-Trap GC/MS In Comparison with Conventional Hop Essential Oil Analysis, J. Agric. Food Chem. 2012, 60, 2785-2792. DOI:10.1021/jf205002p

33. M. Riu-Aumatell, P. Miró, A. Serra-Cayuela, S. Buxaderas, F. Lopez-Tamames, Assessment of the aroma profiles of low-alcohol beers using HS-SPME-GC-MS, Food Res. Int. 2014, 57, 96-202. DOI:10.1016/j.foodres.2014.01.016

34. M. Steinhaus, P. Schieberle, Comparison of the most odor-active compounds in fresh and dried hopcones(Humulus lupulus L.variety Spalter Select) based on GC-olfactometry and odor dilution techniques, J. Agric. Food Chem. 2000, 48, 1776-1783. DOI:10.1021/jf990514l

35. S. Hanke, M. Herrmann, J. Rückerl, C. Schönberger, W. Back, Hop Volatile Compounds (part II): Transfer Rates of Hop Compounds from Hop Pellets to Wort and Beer, Brewing Sci.-Monatsschrift. Brauwiss. 2008, 61, 140-144.

\section{Povzetek}

Edinstvena sestava eteričnega olja hmelja in grenkih smol je ključnega pomena za aromo, kar je pomembno za sprejemanje piva s strani potrošnikov. $\mathrm{V}$ tem poskusu je bilo isto pivo razdeljeno na štiri dele, vsak je bil hmeljen drugače. Za določitev dinamike hitrosti izomerizacije so bile izvedene kontinuirane meritve koncentracij alfa- izo-alfa-kislin. Prav tako so bile med postopkom merjene tudi koncentracije določenih komponent eteričnega olja hmelja, da bi razumeli dinamiko njihovega prehoda v pivo. Največji izkoristek izomerizacije alfa-kislin (18,1 \%) je bil dosežen po 100 min varjenja pivine. Daljše vretje povečuje zmanjšanje koncentracij izo-alfa-kislin, kot tudi komponent eteričnega olja. Hladno hmeljenje vpliva ne le na aromo piva, ampak tudi na grenkobo. 